\title{
Philosophical reflections on Darwin and evolutionary theory
}

Did Darwin Write the Origin Backwards? by Elliott Sober. Prometheus, 2011. US\$21 (232 pp.) ISBN 1616142308

\section{Massimo Pigliucci}

Philosophy Program, The Graduate Center, City University of New York, New York, NY 10016, USA

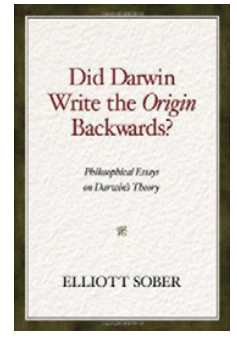

Few scientists are conscious of the distinction between the logic of what they write and the rhetoric of how they write it. This is because we are taught to write scientific papers and books from a third-person perspective, using as impersonal (and, almost inevitably, boring [1]) a style as possible. The first chapter in Elliott Sober's new book examines the difference between Darwin's logic and his rhetoric in The Origin, and manages to teach some interesting and insightful historical and philosophical lessons while doing so.

For instance, from a logical perspective of Darwin's two conceptual pillars - the idea of common descent and that of natural selection - the first should take precedence in the narrative, because one needs historical information to test adaptive hypotheses (if only evolutionary psychologists kept this simple tenet constantly in mind they would produce fewer just-so stories and more solid science [2]). Instead, Darwin begins his book with natural selection and lets the idea of common descent emerge gradually throughout the rest of his magnum opus. Why? Because this 'backwards' sequence was rhetorically much more effective, as Sober elegantly demonstrates. Yet another example that Darwin was not just a brilliant scientist; he was a cunning one too.

There is much else that both biologists and philosophers of science can gain from reading this book, despite the fact that it is actually a collection of essays, some published and revised, some never printed before. The second and third chapters, for instance, take up two well-known workhorses in evolutionary biology - group selection and the evolution of sex ratios - and actually manage not only to present those complex topics and the scientific controversies that have characterized them in exceptionally clear fashion, but also to add original thoughts in both areas. As we all think we know, George Williams allegedly dealt a death blow to the idea of group selection, but Sober clearly shows that this is true only for a particularly naive concept of the phenomenon, that Williams got a number of things wrong, both factually and logically, and that the idea is very much alive and well (although still controversial) under the modern guise of multi-level selection theory [3].

The story concerning sex ratios is even more intriguing and is probably far less known to biologists than the one about group selection. Standard textbook treatments begin with Fisher's solution to the problem, but Sober points out that Darwin already had interesting things to say about it, and that there was a significant literature that included

\footnotetext{
Corresponding author: Pigliucci, M. (massimo@platofootnote.org).
}

ingenuous (if flawed) arguments - for instance advanced by Arbuthnot in 1710 (p. 88) - to show that the slight male bias at birth in humans is the result of intelligent design. More importantly, Fisher - while citing Darwin - inexplicably missed the fundamental work of Carl Düsing, published in 1884 (p.106), in which the author formulated a mathematical argument for even sex ratios at reproduction, an argument that anticipated Fisher's own take, which was, surprisingly, expressed only verbally.

Speaking of intelligent design, the fourth and last chapter in Sober's book (there is also a postscript that resumes discussion of several of the main themes treated in the main body) concerns naturalism, the methodological or philosophical position (depending on one's leanings and purposes) that separates Darwin's theory from Paley-style natural theology. Here Sober provides one of the most sophisticated accounts to date of the relationship between methodological naturalism - on which science is founded and theological accounts such as Intelligent Design 'theory' and theistic evolution. He probably manages to irritate theologians and militant atheists alike, which is a good reason why philosophers and scientists from both camps really ought to read this chapter. Sober states that methodological naturalism is 'the thesis that science should not make claims about the existence and properties of a supernatural deity' (p. 121) and then goes on to dissect such a thesis. Sober agrees that science can - and does - refute specific religious claims, such as that the earth is tens of thousands instead of billions of years old. Then again, he also arrives at the conclusion that the so-called new atheists' contention that science can falsify 'the God hypothesis' is misguided, because one cannot coherently talk about hypotheses in a theological context. He appropriately ends his balanced chapter on naturalism with a quote from Jacques Monod, pioneer of molecular biology and author of the classic Chance and Necessity [4]: 'Any confusion between the ideas suggested by science and science itself must be carefully avoided'. Indeed.

\section{References}

1 Sand-Jensen, K. (2007) How to write consistently boring scientific literature. Oikos 116, 723-727

2 Kaplan, J. and Pigliucci, M. (2001) Genes 'for' phenotypes: a modern history view. Biol. Philos. 16, 189-213

3 Okasha, S. (2006) Evolution and the Levels of Selection, Oxford University Press

4 Monod, J. (1972) Chance and Necessity: An Essay on the Natural Philosophy of Modern Biology, Vintage Books 